\title{
Tackling of Corruption in India by Recently Enacted Penal Laws
}

\author{
By Pradeep Kumar Singh*
}

\begin{abstract}
Corruption is not only a crime but also a serious social problem which further begets many other problems like black money, black market, money laundering etc. Corruption affects infrastructural development, economic growth, prosperity of nation and ultimately erodes public faith in law, government, governmental policies and governance. In this era of globalization, and science and technology, anything happening in one nation affects all other nations and persons throughout world. When in one nation public servants commit corruption and they have corrupt mentality; such situation affects not only the nation concerned but also the world community. It is always important requisite that the legal regime to tackle problem of corruption has to be reviewed and amended to suit the requirements of criminal justice system. In India recently legal regime relating to corruption has been amended for effective tackling of corruption and corruption related problems. In this paper analysis will be made regarding effectiveness of recently enacted laws to deal with corruption.
\end{abstract}

Keywords: Benami property; Black money; Corruption; Confiscation; Criminalisation; Money laundering; Society; Tax evasion.

\section{Introduction}

Corruption is a serious challenge before the criminal justice which erodes faith of citizenry in law, rule of law and good governance. Without any exception both the developed and developing nations are seriously affected by alarming increase in corruption and corrupt practices but with passing time, development, education, and market based economy impact of corruption in developing countries is becoming more devastating. In developed countries also corruption is graver problem but there society is more developed in various references particularly infra-structure and economy development, therefore corruption is not as problematic as it is in developing countries. In developing countries like India, corruption affects infrastructural development, and ultimately serious setbacks are caused to the whole economy and over-all development of the country. Corruption augments demoralizing effect and bumps up criminogenic forces particularly for socio-economic criminality. Corruption is increasing leaps and bounds which engulfs whole developmental activities particularly infra-structure development. Corruption is not only dangerous problem in itself but it is mother of various problems which cumulative impact is complete damaging of social value system and social developmental process.

*PhD, Professor, Faculty of Law, Banaras Hindu University, Varanasi, Uttar Pradesh, India. Email: pradeepsinghk6@gmail.com. 
Corruption is major problem in India affecting the whole developmental and welfare activities, and further, every aspect of life of people; without tackling corruption India cannot attain its goal of development of society, well-being of citizenry, and prosperity of the nation. Corruption affects every aspect of national development particularly infra-structural development. Recently Indian legislature has enacted some modern and effective penal laws to check the menacing problem of corruption. Corruption is not simple problem but complicated one; it is necessary to enact modern, efficient and sufficient penal laws to effectively deal the corruption, corrupt practices and corrupt mentality.

\section{Prevention of Corruption Act 1988}

Initially Prevention of Corruption Act was enacted in 1947 to tackle the problem of corruption, but with passing time it was realised that the rate and seriousness of corruption cases are increasing and the aforesaid Act is needed to be modernised, therefore, in 1988 Prevention of Corruption Act 1947 was repealed and Prevention of Corruption Act 1988 was enacted. To make it modern and effective in dealing with corruption problem in 2018 Prevention of Corruption (Amendment) Act 2018 has been enacted which makes complete change to corruption related legal regime. Previously gratification was taken as monetary gratification only and such concept was seriously weakening efforts to tackle corruption as when public servant would have taken any other sort of gratification. In corruption activities public servant not only takes pecuniary considerations but it may be of varied nature. In Section 2 of Prevention of Corruption Act 1988 by Amendment Act 2018 definition of 'undue benefit' is added which means any gratification other than legal remuneration, and further, by adding Explanation to this clause 'gratification' is defined it is not limited to pecuniary gratification or gratification estimable in money. Thereby, impact of the Act has been made wider to include any kind of improper act of public servant committed for any kind of favour or benefit. When undue advantage and gratification are read together, it makes this Act as very effective instrument for dealing with problem of corruption and corrupt practices.

By Section 3 of Prevention of Corruption (Amendment) Act 2018 Section 4 of Prevention of Corruption Act is amended and now it directs for speedy trial in corruption cases. Speedy disposal of cases have effective impact over dealing with crime problem. When corrupt person is punished speedily with infliction of severe sentence, it may be lesson for corrupt public servant and persons with corrupt mentality. Societal reaction against corruption is also sharpened by speedy disposal of case. Now after amendment sub-section 4 of Section 4 of Prevention of Corruption Act directs for day to day hearing and taking endeavour for conclusion of trial within a period of two years and in case trial is not concluded within such period then to record reasons in writing and period of trial may be extended further but in one instance it can be extended only for six months and provisions contained in sub-section 4 of Section 4 of the Act ultimately provides that the maximum period for trial shall not be ordinarily more than four years; here 
ordinarily term is used, it means in exceptional situation trial period may be extended for further period also. Lokpal has also crucial role in establishment of special courts for trial of corruption cases. Section 35 (1) Lokpal and Lokayuktas Act 2013 provides that for trial of cases under Prevention of Corruption Act 1988 and Lokpal and Lokayuktas Act 2013 Central Government shall constitute such number of special courts as recommended by Lokpal.

Through Amendment Act of 2018 Section 7, 8, 9, and 10 are completely substituted to make the Act effective to deal with corruption problem in effective manner. ${ }^{1}$ Section 7 of Act prescribes punishment for corruption committed by public servants in performance of his official duties or attempt or abetment. Section 7 of Prevention of Corruption Act 1988 declares that the taking undue advantage in performance of an official act is an offence. Section 7 of Act after amendment in 2018 has become wider and effective; when undue benefit has been taken or attempt is made to obtain undue benefit for doing or forbearing to do an official act or showing or forbearing to show favour or for rendering or attempting to render any service, the act committed by public servant will become corrupt act punishable under provisions contained in the Section 7 of the Act. Explanation 1 to Section 7 of Act clarifies that offence is committed as soon as undue benefit is involved, obtained, accepted or attempted to obtain, it is regardless whether act was committed or not, it will be corruption. Explanation 2 to Section 7 of Act clarifies that it is immaterial whether public servant has taken undue advantage directly or through some third person, act of such public servant is punishable offence under Section 7 of Act. Further, public servant has taken undue advantage for doing corrupt act himself or using his position and influence over another public servant for committing corrupt act is crime under Section 7 of the Act. By Amendment Act 2018 punishment prescribed under Section 7 has been enhanced; previously prescribed punishment was imprisonment for not less than six months and extended up to five years and also liable to fine, now prescribed punishment is imprisonment for not less than three years but which may be extended to seven years and is also liable to fine. Section 7 of Act imposes punishment on public servant for corruption; Section 7-A is included in the Prevention of Corruption Act 1988 by Amendment Act 2018 which penalises a person who is not public servant and he takes undue advantage to induce a public servant to commit corruption, such act of such person is punishable with imprisonment not less than three years which may extend to seven years and also liable to fine.

Giver of undue advantage lures public servant to become corrupt. Section 8 (1) of Act prescribes punishment for giving undue advantage; giver of gratification is main cause of corruption. If giver in corruption case would not provide illegal gratification, public servant would not become corrupt person. Section 8 of Act prescribes imprisonment for a term which may extend to seven years or with fine

\footnotetext{
${ }^{1}$ By Section 4 of Prevention of Corruption (Amendment) Act 2018 Section 7, 8, 9 and 10 are completely substituted. In un-amended Act of 1988 there was compulsory requirement to prove that the gratification other than legal remuneration was taken as motive or reward for corrupt acts and proving of such motive was difficult as in corruption cases, generally, evidences are not available in traditional reference. Now explanation added to section 7 of Act clarifies that only taking undue advantage is sufficient for attracting penal provisions contained in Section 7 of Act.
} 
or both. Punishment prescribed in this section does not prescribe mandatory minimum imprisonment as punishment, and further, court has discretion to impose imprisonment or fine or both. Third Proviso to Section 8 (1) provides that when giver of undue advantage is commercial organisation, it shall be punishable with fine only. Situation mentioned in third proviso to Section 8 (1) is dealt in detail in provisions contained in Section 9 of Act which provides in reference to giving of undue benefit by the commercial organisation that when any person associated to such organisation gives undue benefit to public servant then such organisation shall be punishable with fine. Commercial organisation shall have defence in criminal prosecution that such organisation has adequate procedure to prevent the persons associated with it from doing such kind of acts. Section 9 (3) (c) of Act clarifies who are the persons associated with commercial organisation for whose act commercial organisation is penalised, according to it such person performs services for or on behalf of commercial organisation. Explanation 2 to Section 9 (3) of Act provides that in deciding whether person is associated to commercial organisation, all the relevant circumstances shall be taken into consideration. Whenever commercial organisation is involved in giving undue benefit punishable under Section 9 of Prevention of Corruption Act then Section 10 imposes imputed liability on director, manager, secretary or other officer of such commercial organisation that such offence is committed with the consent or connivance of such officer/officers and such officer shall be liable for punishment of imprisonment for term which shall not be less than three years but which may extend to seven years and shall also be liable to fine.

Giver of illegal gratification are usually victim and compelled by public servant to pay the illegal gratification, therefore, there is need to protect innocent common man who is innocent person, he is actually victim of corruption. Further, in struggle against corruption such victim is main recourse to obtain information regarding corrupt public servant and acts of corruption, such persons are main witnesses and measures to collect evidences. Section 8 of the Prevention of Corruption Act substituted through Amendment Act considers the need of criminal justice system and provides protection to compelled giver of gratification; such person is not criminal but victim of crime of corruption. First Proviso to Section 8 (1) provides that section shall not apply where a person is compelled to give such undue advantage and sub-section (2) of Section 8 of Prevention of Corruption Act provides that sub-section (1) shall not be applicable when giver of undue advantage informs law enforcement agency and to assist them gives or promises to give undue advantage.

In Prevention of Corruption Act Section 13 deals with criminal misconduct and in un-amended Act it was much confusing and it was usually affecting the efficacy. Prevention of Corruption Act has substituted sub-section (1) of Section 13 and now it provides two instances when acts of public servant may amount to criminal misconduct - (1) when public servant fraudulently or dishonestly misappropriates any property entrusted to him or property under his control or public servant facilitates another person for misappropriation of such property. It is very wider provision and covers situation of enriching of public servant on cost of public property. This provision may sufficiently deal with abuse, misuse and 
misappropriation of public fund. (2). When public servant illegally enriched during holding the office. It is also very wider provision may cover all the situations of public servant found in possession of property and assets more than his known sources of income and it is completely cleared by Explanation 1 and 2 to Section 13 (1) of the Act. $^{2}$ To effectively deal with corruption most crucial action is confiscation of property accumulated by corrupt acts, this is taken care by various penal Acts recently enacted, Prevention of Corruption (Amendment) Act 2018 also provides provisions in aforesaid reference. Chapter - IV A has been added which consists Section 18 A which makes attachment and confiscation of property obtained by corruption more effective by prescribing that besides Prevention of Money Laundering Act provisions contained in Criminal Law Amendment Ordinance 1944 shall also be applicable. Prevention of Money Laundering is applicable for acts of money laundering, where matter is not amounting to money laundering then attachment and confiscation of property may be under Criminal Law Amendment Ordinance $1944 .^{3}$ Further for effective dealing with corruption creation of deterrence in the mind of corrupt public servant is necessary. Prevention of Corruption (Amendment) Act 2018 has increased the punishments prescribed for offences punishable under the Act 1988, further, for subsequent conviction for corruption Amendment Act prescribes enhanced punishment. Thereby, Prevention of Corruption Act provides more severe punishment for habitual corrupt public servant. Section 14 of prevention of Corruption Act 1988 is substituted by Section 8 of Prevention of Corruption (Amendment) Act 2018 and it provides that on second or further conviction prescribed punishment shall be of imprisonment for term not less than five years which may extend to ten years and shall also be liable to fine.

Public servant is also needed to be protected for proper discharge of his official duty and in it not only he has interest but also society has interest. Proper discharge of his public duty by public servant is necessary for societal development and excellence. Public servant should have fearless environment for discharge of his duty; honest public servant should not have fear that some vested interest may initiate proceeding against him and his social reputation may be affected by his arrest or made accused in false case of corruption. In Criminal Procedure Code in Section 197 protection is provided to public servant for all and

\footnotetext{
${ }^{2}$ Explanation 1 and 2 to the Section 13 (1) of Prevention of Corruption Act clears that illegal enriching of public servant means persons found in possession of more property than his known sources of income is criminal misconduct. Explanations provides - "Explanation 1- A person shall be presumed to have intentionally enriched himself illicitly if he or any person on his behalf, is in possession of or has, at any time during the period of his office, been in possession of pecuniary resources or property disproportionate to his known sources of income which the public servant cannot satisfactorily account for.

Explanation 2 - The expression "known sources of income" means income received from any lawful sources."

${ }^{3}$ Criminal Law Amendment Ordinance is applicable for attachment and confiscation of property obtained by commission of crime; jurisdiction in Ordinance 1944 is given to District Judge but Section 18 A of Prevention of Corruption (Amendment) Act 2018 confers such jurisdiction on Special Judge appointed under Prevention of Corruption Act 1988. For attachment and confiscation of property obtained by corruption, various enactments are relevant like LokPal and Lokayukta Act, Benami Property Act, Criminal Procedure Code etc.
} 
every kind of prosecution by prescribing requirement of prior sanction for taking cognizance of criminal case; in Section 19 of Prevention of Corruption Act special provision is given for prescribing special procedure for corruption cases that court cannot take cognizance of corruption case without previous sanction of related Government or competent authority. Now by Amendment Act 2018 time limit for disposal of matter relating to grant of previous sanction has been prescribed in Section 19 of Act of 1988 according to which matter for grant of previous sanction has to be decided within three months from the date of receipt of proposal requiring grant of previous sanction and when there is need of legal consultation for disposal of such matter then such period may be extended by one month. By prescribing time limit for disposal of matter relating to grant of previous sanction may cure the problem of delaying of matter and affecting of criminal justice. Further, it may be conducive for effective dealing with corruption cases. Private person may seek previous sanction of Government or competent authority for initiation of prosecution only when he is complainant and his complaint is not dismissed by Court under Section 203 of Criminal Procedure Code 1973, otherwise only law enforcement agency is permitted to seek previous sanction. Initiation of investigation particularly arrest may affect the reputation of a public servant, therefore, to protect honest public servant it is necessary that there should be proper procedural safeguards and now it is provided by addition of a new provision Section 17 A in the Prevention of Corruption Act 1988. ${ }^{4}$ Section 17 A of the Act provides that inquiry or investigation can only be conducted after obtaining the previous approval from the Government or competent authority. Normally in cognizable case investigating agency is competent to initiate investigation without obtaining any authorisation but this new requirement imposes restriction on the power of investigating agency. But Second Proviso to Section 17 A of Prevention of Corruption Act imposes time limit of three months on Government and competent authority to dispose matter relating to grant of previous approval to investigating agency and this time limit may be extended for one month but maximum time which may be available to concerned authority for taking decision about grant of previous approval is four months. This provision also implicitly clears that public servant cannot be arrested on charge of commission of corruption without obtaining prior approval from the concerned authority but First Proviso to Section 17 A of the Act clears that such approval shall not be needed for case involving arrest of a person on spot on the charge of accepting or attempting to accept undue advantage. Hereby, when a public servant is arrested at the spot while he is in process of taking or attempting to take undue advantage then there is no need of previous approval for arrest and investigation in the case.

\footnotetext{
${ }^{4}$ Section $17 \mathrm{~A}$ is added in Prevention of Corruption Act by Section 12 of Prevention of Corruption (Amendment) Act 2018.
} 


\section{Prevention of Money Laundering Act 2002}

It is primary criminological consideration that the causation of crime should be kept in focus in criminal law enactment and criminal law enforcement. In corruption, major and primary cause is greed and materialism and to satisfy it public servant commits corruption; money is obtained through corrupt practices which is concealed or invested and projected as untainted property. Such property also creates problem of black money; corruption and black money are interrelated problem. Corruption creates black money and black money creates corruption. If proceed of corruption is sternly dealt and confiscated, a public servant indulged in corruption or public servant making mind to commit corruption may not think to commit corruption. ${ }^{5}$ Corrupt person should have lesson that corruption may not be beneficial; even after commission of corruption, money obtained may not be used but may be confiscated.

Concealing of proceed of corruption is major component in crime of corruption; concealing and projecting proceeds of crime as untainted money is called as money laundering; Prevention of Money Laundering Act 2002 declares it as crime. ${ }^{6}$ Section 2 (1) (p) of Prevention of Money Laundering Act provides that Money Laundering has the meaning assigned to it in Section 3, thereby, when meaning of money laundering is attempted to inferred from Section 3 of the Act 2002, money laundering is an offence of concealing or investing or projecting proceed of crime as untainted money. Money laundering is commission of any offence mentioned in Section 3 of the Act 2002. ${ }^{7}$ Section 3 of Act 2002 declares every act any way related to concealing of proceeds of crime and projecting as untainted property as crime. In original Act money laundering activities were not specifically specified, thereby, it was creating confusion; by Finance Act 2019 in Section 3 of Prevention of Money Laundering Act 2002 an Explanation has been added which clears that a person is guilty of money laundering if he is directly or indirectly attempted to indulge or knowingly assisted or knowingly he is party or actually involved in any manner in - concealment or possession or acquisition or use or projecting as untainted money or claiming as untainted money. By addition of Explanation to Section 3 now act of money laundering is clearly specified and it covers every aspect relating to money laundering, whether committed in one manner or other; and further, it also covers every person concerned with money laundering, whether connected directly or indirectly. Furthermore, this Explanation

\footnotetext{
${ }^{5}$ In Ancient Indian law there was clear direction for confiscation of property obtained by corruption. In Manu-smriti which has been most acknowledged ancient law scripture in India king was directed to confiscate the whole property of corrupt public servant (Manu-smriti. IX. 231). Confiscation of property is main measure to deal with corruption. when public servant losses his property accumulated by corruption, and further, punishment is also imposed for corrupt act then he and also other potential corrupt public servant get clear lesson that corruption is undesired and painful; never such act has to be committed.

${ }^{6}$ Section 3 of Prevention of Money Laundering Act 2002.

${ }^{7}$ Money laundering is declared as an offence $\mathrm{u} / \mathrm{s} 3$ of Prevention of Money Laundering Act 2002 and Section 4 of this Act prescribes punishment that it is punishable with rigorous imprisonment for a term which shall not be less than three years but which may extend to seven years and shall also be liable to fine.
} 
in its clause (ii) clarifies that acts relating money laundering is continuing crime and it continues till such person is enjoying proceeds of crime. ${ }^{8}$ Money laundering is crime relating to proceed of crime and proceed of crime is defined in Section 2 (1) (u) of Prevention of Money laundering Act as property obtained or derived from criminal activity relating to a scheduled offence or value of any such property. Hereby, issue relating Proceed of crime is crucial and material for effective action against money laundering. Definition of proceed of crime given in Act enacted in 2002 was not clearly showing that whether proceed of crime is property obtained by commission of scheduled offence only or it is also including property obtained by commission of some offence relating to scheduled offence. To clarify and to make law effective to deal with money laundering in Section 2 (1) (u) of Prevention of Money Laundering Act 2002 one Explanation has been added by Section 192 of Finance Act 2019 which clearly mentions that proceed of crime not only derived or obtained from the scheduled offence but also any property which may be directly or indirectly be derived or obtained as a result of any criminal activity relatable to scheduled offence. This explanation clears that not only property derived from scheduled crime is proceeds of crime but also profit obtained by investment of such property is proceed of crime. Further, not only property obtained by schedule offence is proceed of crime and Section 3 of Act shall be applicable but also property obtained by offence which is not scheduled offence but relatable to scheduled offence is also proceed of crime and Section 3 of Act 2002 shall be applicable.

Only imposition of sentence may not be sufficient for tackling the problem of money laundering and ultimately the crime from which such proceeds of crime has been obtained but it is required that the proceeds of crime be identified and confiscated. For identification and confiscation of proceeds of crime Directorate is established and director, deputy director and assistant director are empowered to attach the proceeds of crime provisionally for maximum period of one hundred eighty days. Then matter is referred to adjudicatory authority. After completion of proceeding if it comes out that the property is proceeds of crime, attachment of property is confirmed. Against order of adjudicatory authority appeal may be filed before Appellate Tribunal established by Central government. By Section 195 of Finance Act 2019 Section 12 AA has been added in the Prevention of Money Laundering Act 2002 which prescribes that whenever any financial transaction takes place the reporting entity ${ }^{9}$ has to verify identity of the person participating in financial transactions as per provisions contained in Aadhar (Targeted Delivery of

\footnotetext{
${ }^{8}$ Clause (ii) of Explanation added by Section 193 of Finance Act 2019 in Section 3 of Prevention of Money Laundering Act 2002 provides: "the process or activity connected with proceeds of crime is a continuous activity and continues till such time a person is directly or indirectly enjoying the proceeds of crime by its concealment or possession or acquisition or use or projecting it as untainted property or claiming it as untainted property in any manner whatsoever".

${ }^{9}$ Financial and other institution mentioned as reporting entity under Chapter IV of Prevention of Money Laundering Act 2002. Financial institution, banking companies and other intermediaries through whom financial transaction is made has responsibility to maintain the record of transactions and provide documents and information to various instrumentalities functioning check problem of money laundering.
} 
Financial and other Subsidies, Benefits and Services) Act 2016. Further, reporting entity has to obtain information regarding ownership, financial position, source of funds and intended nature of relationship between transaction parties. Whenever reporting entities identifies have suspicion relating to use of proceeds of crime in transactions, it has to increase future monitoring including greater scrutiny of business with such client and in such case reporting entity has maintain records of transaction between such client making such transaction and reporting entity. When reporting entity identifies suspicious transaction (it is named as specified transaction), reporting entity has to apply due diligence over such client and his transaction and record of information gather in this reference has to maintained for period of five years from the date of transaction between client and reporting entity. ${ }^{10}$

Offence of money laundering punishable under Sec. 4 of the Act is declared as cognizable and non-bailable. Offences relating to concealment of Proceed of crime is dealt under Prevention of Money Laundering Act and provisions have declared them as cognizable and non-bailable but offence of which proceed is dealt herewith itself may be declared as non-cognizable and/or bailable in Criminal Procedure Code; such confusion is need to be specifically dealt with and clarified, therefore, by Section 200 of Finance Act 2019 one Explanation has been added in Section 45 of Prevention of Money Laundering Act 2002 which specifically clarifies that all offences under this Act shall be cognizable offences and non-bailable offences notwithstanding anything contrary contained in the Code of Criminal Procedure 1973. Therefore, for all the offences under Prevention of Money Laundering Act 2002 law enforcement agency is empowered to arrest without warrant subject to due observance of conditions mentioned in Section 19 of Prevention of Money Laundering Act 2002. ${ }^{11}$ This offence is committed by organised gangs and also they may have international connections, therefore, for investigation of offence and attachment of proceeds of crime international cooperation may be required. Section 56 empowers Central Government to make agreement with other countries for enforcement of this Act and exchange of information for prevention of money laundering. On request of investigating officer court may issue letter of request to court authority in the other country for collection of evidences.

\footnotetext{
${ }^{10}$ Section 12 AA (4) Added in Prevention of Money Laundering Act 2002 by Section 195 of Finance Act 2019.

${ }^{11}$ Section 19 of Prevention of Money Laundering Act directs that law enforcement agency may, on reason to believe that a person is guilty of offence under the Act derived from material recovered from possession of such person, arrest without warrant. Law enforcement agency must record reason of such believe in writing. Such arrested person must be produced before the Judicial Magistrate or Metropolitan Magistrate within twenty four hours of his arrest excluding time required for the journey from the place of arrest to the court. Law enforcement agency has to forward, all the materials recovered from possession of such arrested on the basis of which law enforcement has formed such believe that he is guilty of offence under this Act, to the Adjudicating Authority.
} 


\section{Prohibition of Benami Property Transactions Act 1988}

Corruption is mainly committed for obtaining illegal gratifications particularly in money terms and after obtaining money it is invested in purchase of properties. Better method to tackle problem is to hit hard on objective of crime commission. In case of corruption, crime is committed to get more and more money. When such money or property obtained by such money is searched and confiscated, person may not commit crime because he will have lesson for future and also it will be for potential corrupt persons that there is no benefit in committing corruption as whatever obtained by crime commission may be confiscated. In 1988 Benami Transactions (Prohibition) Act 1988 was passed. Benami property is major measure to use unaccounted money obtained through corruption. This Act has been enacted to deal with problem of benami property ultimately to check problem of corruption, black money and other kinds of organised crimes.

The Act of 1988 was having many loopholes and it was not achieving its desired aim to check the problem of benami property, this Act was containing merely nine sections and no procedure and competent authorities were prescribed for enforcement of law. Further, un-amended Act did not prescribe any penalty or punishment for participating in benami transaction. Un-amended Benami Transaction Act 1988 was ineffective. Therefore to make the law effective Benami Transactions (Prohibition) Amendment Act 2016 was passed and Benami Transactions (Prohibition) Act 1988 was renamed as Prohibition of Benami Property Transactions Act 1988. This Act has been made to find out benami property and confiscate it. Benami property is obtained in the name of some other person or even such person may be fictitious person. Person who is holding the property, he may exist and identifiable, but he is not real owner of property, only he is holding property for benefit of person invested money in the property. In some cases person in whose name property is shown may have lend his name for the purpose of using name to show as owner of property. In some cases person whose name is used may not be existing, he may be fictitious person. Person who holds the benami property is called as benamidar ${ }^{12}$ and person for whose benefit benami property is held by benamidar is called beneficial owner ${ }^{13}$. Section 4 of Benami Transactions (Prohibition) Amendment Act 2016 has substituted the whole Section 2 of Prohibition of Benami Property Transactions Act 1988. Section 2 (8) of Prohibition of Benami Property Transactions Act 1988 defines benami property as any property which is the subject matter of benami transaction and also includes the proceeds from such property. The proceeds of benami property also form benami property. Hereby, property is benami or not, depends on whether transaction relating to property is benami transaction. Whenever transaction relating to any property is benami transaction, the property and proceed of such

\footnotetext{
${ }^{12}$ Section 2 (10) Prohibition of Benami Property Transactions Act 1988. This definition clears that benamidar may be existing and alive person or fictitious person. In case of existing person some benamidar may have lend his name for holding such property. Lending the name has reference that such person is taking money for use of his name for holding the benami property..

${ }^{13}$ Section 2 (12) Prohibition of Benami Property Transactions Act 1988.
} 
property shall be benami property. Benami transaction is transaction or arrangement by which a property is transferred to or held by a person but consideration of such property is paid by another person and such property is held by benamidar for immediate or future benefit of person who provided the consideration. ${ }^{14}$ But when property is held in such a situation by karta or member of Hindu undivided family for benefit of members of family or spouse or child or person in fiduciary relationship like trustee, executor or director of company etc., the transaction shall not be benami transaction and property shall not be benami property. Further, when person paying the consideration for property is joint owner with his near relatives like sister, brother etc. and paid consideration for property is paid out of known sources of such person, property will not be benami property. But in all these cases in which property is taken in name of other person and it is not treated as benami property, it is necessary that property must be within known sources of person paying the consideration. Hereby, Amendment Act has made major change in traditional concept of benami property that even when property is taken in name of nearly related if property is more than known sources of person paying the consideration, property shall become benami property and action may be taken under this Act. When person has property in his own name and it is more than known sources, action is taken under relevant laws like law relating to income tax etc.; and when he has taken in name of nearly related like spouse, son, daughter, sister, brother etc. and property is not within known sources of income of person paying consideration, property is benami property and in such situation together with other relevant laws like law relating to income tax provisions of Prohibition of Benami Property Transactions Act 1988 shall also be applicable and effective action may be taken.

When property is taken in name of fictitious person or consideration for property is paid by fictitious person then also transaction is benami transaction and property shall be benami property. ${ }^{15}$ Furthermore, when person who is shown as owner, he is not aware about it or he denies ownership of such property then also transaction shall be benami transaction and property shall be benami property. ${ }^{16}$ Un-amended Act of 1988 dealing with benami property was not prescribing complete measures for tackling problem of benami property but amendment made by Act of 2016 provides effective procedure for dealing with benami property problem, thereby, ultimately problems of corruption and black money. Section 5 of Prohibition of Benami Property Transactions Act 1988 confers power on Central Government to confiscate benami property. ${ }^{17}$ Benamidar cannot transfer property to the beneficial owner; any transfer of benami property to beneficial owner or his representative is declared as null and void. ${ }^{18}$ Section 3 (3) Prohibition

\footnotetext{
${ }^{14}$ Section 2 (9) (A) Prohibition of Benami Property Transactions Act 1988.

${ }^{15}$ Section 2 (9) (B) and (D) Prohibition of Benami Property Transactions Act 1988

${ }^{16}$ Section 2 (9) (C) Prohibition of Benami Property Transactions Act 1988

${ }^{17}$ Section 5 of Prohibition of Benami Property Transactions Act 1988 provides: “Any property, which is subject matter of benami transaction, shall be liable to be confiscated by the Central Government".

${ }^{18}$ Section 6 of Prohibition of Benami Property Transactions Act 1988. Only transfer of benami property from benamidar to beneficial owner is permitted under Section 190 of The Finance Act 2016. Under Finace Act 2016 there was asset declaration scheme and under it person paid
} 
of Benami Property Transactions Act 1988 declares participation in benami transaction on or after enforcement of Benami Transaction (Prohibition) Amendment Act 2016 as an criminal behaviour for which specific penal provisions are prescribed in Chapter VII of the Prohibition of Benami Property Transactions Act 1988. Section 53 (1) contained in Chapter VII of Act declares act of benamidar, beneficial owner and persons abetting benami transaction as criminal acts and sub-section (2) of Section 53 prescribes punishment of imprisonment for term not less than one year but which may extend to seven years and also punishable by fine which may extend to twenty five percent of fair market value of property. Fine imposition is mandatory. There are double pronged blow on benami property, thereby, corruption and black money; property is confiscated under Section 5 and here under Section 53 (2) there is mandatory imposition of fine and it is higher that is twenty five percent of fair market value of property. Generally benamidar and beneficial owner give false information and false documents to conceal benami transaction and benami property, such acts are also declared as crime u/s 54 of Prohibition of Benami Property Transactions Act 1988 and punishments prescribed are of imprisonment for term not less than six months which may extend to five years and also fine which may extend to ten percent of fair market value the property.

Benami Transactions (Prohibition) Amendment Act 2016 has completely changed Benami Transactions (Prohibition) Act 1988; not only name of Act is changed but provisions contained therein are wholly and completely changed. The un-amended Benami Transaction (Prohibition) Act 1988 was containing merely nine sections and provisions were completely incomplete in every reference, neither properly relevant aspects were defined nor regulatory, penal and confiscatory provisions were provided nor proper authorities were established nor adequate procedures were provided to deal with benami property and benami transaction. In amended Act every needed measure is provided for identification and confiscation of benami property; in this regard Authorities (Initiating officer, Approving authority, Administrator and Adjudicating authority) and Appellate Tribunal are established. Amended Act provides provisions for penalizing benami transactions related activities and for it criminal courts, jurisdictions and procedures are provided. In 2019 by Finance Act 2019 some amendments have been made in Section 23, 24, 26, 30, 46, 47, 54 and 55 of Prohibition of Benami Property Transactions Act; these amendments are inserted in reference to calculation of various periods under the Act like limitation period, period for filing of appeal before Appellate Tribunal, period for rectification of error etc. After amendment in 2016 by Benami Transactions (Prohibition) Amendment Act 2016 and in 2019 by Finance Act 2019 The Prohibition of Benami Property Transactions Act 1988 dealing with benami property has become very effective and efficient law, thereby, if this Act is properly enforced, it may effectively and efficiently deal with corruption and related problems.

consideration for benami property declared his asset that it is his property giving evidences and transfer is made within stipulated time then such property will not be confiscated under benami Act (Section 3 Prohibition of Benami Property Transactions Act 1988 ) but now such actual owner shall be dealt under Income Tax Act and other related laws. 


\section{Black Money (Undisclosed Foreign Income and Assets) and Imposition of Tax Act 2015}

Now in the era of globalization person committing corruption, money laundering, tax evasion, black money and other organised crimes operate through across the national borders and internationally. All such crimes are interconnected. In criminal matters usually sovereignty notions of countries which causes problem relating to criminal jurisdiction application and criminals take benefit of such technicality and after commission of crime they run away to some other country or from other country operate commission of crime. In case of commission of corruption and tax evasion money proceed is invested and money laundering related acts are committed in some other country. Through the establishing of fake companies (shell companies) ${ }^{19}$ tax evasion, corruption and black money related offensive acts are committed; there is need of strict actions against them. Corruption problem can be tackled when undisclosed property and income, whether these are within the country or outside country, are effectively identified and proper actions are taken. Black Money (Undisclosed Foreign Income and Assets) and Imposition of tax Act 2015 has been enacted to deal with problem of black money that is undisclosed foreign income and assets. Black Money (Undisclosed Foreign Income and Assets) and Imposition of tax Act 2015 is a taxation enactment which prescribes measures for identifying undisclosed asset and foreign income held outside India, imposition of tax and penalties and its recovery. Section 2 (11) defines undisclosed asset located outside India as an asset or financial interest in any entity in other country in his own name or as beneficial owner and such person has no explanation for source of investment in such property. ${ }^{20}$ Undisclosed asset located outside India is foreign asset held by a person in his own name or name of some other person and such person has not disclosed such asset and it is beyond his known sources of income. If such property is identified, then there will be tax imposition and recovery under this Act

\footnotetext{
${ }^{19}$ Shell Company is company without any active business. Only in paper company is established and generally it has no capital also but on paper it does business and also earns larger profits. It is now used as major measure to make black money as white money, to commit corruption particularly bribe taking, to send money in other country, thereby law enforcement agencies may not take actions effectively. Shell Company is also established in other country and it is used to invest money through it as foreign investment; in this process money obtained in one country is invested in the same country, only it is shown as investment is coming from some other countries. Shell Company is also used for tax evasion in the name of double taxation. Income tax in one country is higher than another country, then person in former country establishes shell company in later country and show that income earned by him is in later country and there he paid the income tax and thereby he avoid payment of income tax in former country where actually he earned his income. Shell Company is also used for taking bribery by sale and purchase of shares. Shell Companies are serious threat for economy, well-being and security of a nation; there is need of strict action against them.

${ }^{20}$ Section 2 (11) Black Money (Undisclosed Foreign Income and Assets) and Imposition of tax Act 2015 provides - " "undisclosed asset located outside India” means an asset (including financial interest in any entity) located outside India, held by the assessee in his name or in respect of which he is beneficial owner, and he has no explanation about source of investment in such asset or the explanation given by him is in the opinion of the Assessing Officer unsatisfactory".
} 
and further, under other relevant Acts (Penal Laws) investigation how such property was obtained and actions thereon. Section 2 (12) Black Money (Undisclosed Foreign Income and Assets) and Imposition of tax Act 2015 defines undisclosed foreign income and asset as total amount of undisclosed income from source located outside India and the value of undisclosed asset located outside India. ${ }^{21}$ Hereby, undisclosed foreign income is value of undisclosed foreign asset and income from such asset. Tackling undisclosed foreign asset is major challenge before law enforcement agencies; without international cooperation it is not possible. Usually by corruption accumulated wealth, tax evaded black money, money obtained by bank fraud are concealed in other country or invested in property and entities in other country. Section 5 of Act 2015 provides measures for calculation of undisclosed foreign income accordingly no deduction of expenditure or allowance or set off of any loss is allowed. Section 3 of Act 2015 provides that for every assessment year commencing from $1^{\text {st }}$ day of April 2016 assessee shall be charged tax at the rate of $30 \%$ of undisclosed foreign income and asset. Income Tax Authority for income tax assessment, imposition and recovery under this Act of 2015 is tax Authority specified in Section 116 of Income Tax Act 1961.

Under Section 10 of Act 2015 Assessing officer after receiving information from income tax authority or any other authority or any other way having information, issues notice for production of documents or evidence or accounts. Assessing officer makes inquiry; if person produces documents, it is considered and if such person fails, officer on basis of collected document and giving opportunity of being heard makes assessment of income tax. For undisclosed foreign income and asset penalty is imposed and it is taken from assessee. Section 41 of Act 2015 prescribes a sum equal to three times the tax computed under Section 10 of the Act. Chapter IV of Act prescribes imposition of various penalties for failure of disclosure of foreign asset, requisite information and default of payment of fine. Chapter V of Black Money (Undisclosed Foreign Income and Assets) and Imposition of tax Act 2015 declares certain specific acts as offences and Section 48 (2) contained in this Chapter provides that provisions of this chapter are in addition to other orders passed under the Act, thereby, income tax imposition order and its recovery may be and also there may be prosecution and imposition of sentence for commission of offence. Further, Section 48 (1) of Act declares that penal provisions contained in Chapter $\mathrm{V}$ of Act are in addition to penal provisions and prosecution under any other law. Hereby, this enactment prescribes much stern law to deal with undisclosed foreign income and asset. When a resident in India not disclose foreign income and asset as required u/s 139 Income Tax Act 1961, his offence is punishable by imprisonment which shall be not less than six months but which may extend to seven years and with fine. ${ }^{22}$ When a person wilfully attempts to evade tax, penalty or interest chargeable or

\footnotetext{
${ }^{21}$ Section 2 (12) Black Money (Undisclosed Foreign Income and Assets) and Imposition of tax Act 2015 provides - " "undisclosed foreign income and asset" means the total amount of undisclosed asset located outside India, referred to in section 4, and computed in the manner laid down in section $5 "$.

${ }^{22}$ Sections 49 and 50 Black Money (Undisclosed Foreign Income and Assets) and Imposition of tax Act 2015.
} 
imposable under this Act, Section 51 (1) of Act 2015 prescribes punishment of imprisonment which shall not be less than three years but which may extend to ten years and with fine. Section 54 of Act 2015 shifts burden of proof by prescribing presumption clause that the court shall presume culpable mental state on part of accused. Accused may give evidence to disprove the presumption that he had no such presumption. Mens rea for commission of offence relating to undisclosed foreign income and asset need not be proved by prosecution but it is presumed by court. Culpable mental state term in Section 54 (1) of Act 2015 is used in wider reference to include intention, motive or knowledge of fact or belief in, or reason to belief, a fact. For such presumption it will be needed that prosecution should prove the fact of the case. Presumption is provided for culpable mental state but there is no presumption regarding act of having undisclosed property in other country or nonpayment of income tax or/and penalty; act has to be proved then mental state is presumed.

In case of commission of offence under this Act by Company, person who was in charge of company or controlling business of company at the time of commission of offence and company both will be deemed as guilty for the offence and penalised. For offence commission by company under this Act presumption clause is applied that person in charge of company or looking after business of company (it also includes unincorporated body and Hindu undivided family) is also guilty, for the aforesaid imputed liability is provided. ${ }^{23}$ Such in charge of company or person looking after business of company at the time of commission of offence may get himself absolved from liability by proving that offence was committed without his knowledge or he exercised due diligence to prevent the commission of crime. When such in charge of company had no knowledge about commission of crime by company or he had knowledge and he exercised due diligence to prevent commission of crime then such person shall not be guilty. Presumptions regarding offences under chapter $\mathrm{V}$ of Act are not conclusive but rebuttable presumption; presumptions are rebuttable by accused through adducing evidences. Director, manager, secretary or other officer whoever is found as provided consent or connivance or on is part neglect was attributable for commission of crime by company, shall also be deemed guilty and penalised. When Company is found guilty, for offence punishable by imprisonment and fine both, company shall be punished with fine only and persons (in charge of company, director, manager etc.) shall be punished with punishment prescribed for offence. ${ }^{24}$ For initiation of prosecution under Chapter V of Act prior sanction of principal Commissioner or Commissioner or Commissioner (Appeals) as the case may be necessary. ${ }^{25}$ Section 80 of Act 2015 gives trial competency to Court of Metropolitan Magistrate or Judicial Magistrate first class or superior criminal courts. Black Money (Undisclosed Foreign Income and Assets) and Imposition of

\footnotetext{
${ }^{23}$ Section 56 (1) Black Money (Undisclosed Foreign Income and Assets) and Imposition of tax Act 2015 .

${ }^{24}$ Section 56 (4) Black Money (Undisclosed Foreign Income and Assets) and Imposition of tax Act 2015.

${ }^{25}$ Section 55 Black Money (Undisclosed Foreign Income and Assets) and Imposition of tax Act 2015 .
} 
tax Act 2015 is very crucial enactment; proper and effective enforcement of provisions of this Act may be effective measure to tackle corruption and black money.

\section{Lokpal and Lokayuktas Act 2013}

Nation works through its public servants, thereby, present and future wellbeing of nation, citizenry and ultimately of whole world community depend on honesty, integrity, ability and humanity of public servant. As and when allegations are made against public servant or otherwise information is available for corruption commission by public servant, it is necessary that matter be inquired and proceeding should be initiated for penalizing corrupt public servant. Further, it is responsibility of state itself to keep vigil over public servants that they are not misusing powers and indulged in corrupt practices. Such actions on part of state attain public faith and create anti-criminogenic environment, and further, enhances deterrence in public servant thereby, they may not commit corruption. Considering aforesaid requirements, in 2013 for establishment of Lokpal at Union and Lokayukta at state level, conferment of powers and procedures, one crucial and important Act was enacted by Union legislature. Lokpal and Lokayuktas Act 2013 specifies the objective that it is enacted to inquire into, investigation and prosecution of allegations of corruption against certain public functionaries.

Under Chapter III and Chapter IV Inquiry Wing and Prosecution wing are established in Lokpal. Section 20 of Lokpal and Lokayuktas Act 2013 provides that Lokpal after receiving allegation of corruption may make preliminary inquiry by its inquiry wing or direct any investigating agency. Lokpal has jurisdiction in reference to Prime Minister ${ }^{26}$, Minister of Union, Member of Parliament, public servants, and employees and officers of board, corporation, authority, company, society, trust or autonomous body. When prima facie case exists then Lokpal may direct any investigating agency for investigation. ${ }^{27}$ When allegation of corruption is against public servants belonging to Group A, B, C or D then Lokpal will direct Central Vigilance Commission for preliminary inquiry. Central Vigilance Commission submits report of preliminary inquiry before the Lokpal. Whether preliminary inquiry is made by inquiry wing of Lokpal or any other body, on prima facie establishment of allegation Lokpal directs any investigating agency including Central Bureau of investigation for making investigation in the case. Before directing investigation Lokpal gives opportunity of hearing to public servant. Section 20 (5) Lokpal and Lokayuktas Act 2013 specifies that investigation agency shall complete investigation as expeditiously as possible and maximum period for completion of investigation is determined as six months from

\footnotetext{
${ }^{26}$ Section 14 Lokpal and Lokayukta Act 2013 provides that in reference to Prime Minister, Lokpal cannot initiate inquiry or cause to initiate inquiry in matter relating to international relations, external and internal security, public order, atomic energy and space. Whenever any inquiry is to be made against Prime Minister it is essential requisite that Chairperson and all the members considered matter and at least two third members have approved the inquiry.

${ }^{27}$ Section 20 (1) (b) Lokpal and Lokayuktas Act 2013.
} 
the date of order. But some cases may be complicated in which more time may be needed for completion of investigation, in such case Lokpal may extend time limit for investigation for six months at a time. ${ }^{28}$ Hereby, balance is tried to be made between fixed time for investigation and more time need for complicated case to make investigation, thereby, speedy investigation is ensured. Corruption cases are such which affect the whole society, in such case speedy and effective investigation is needed. Lokpal has power of superintendence over and to give direction to Central Bureau of Investigation for matters referred by it to investigation agency. ${ }^{29}$ When Lokpal has reason to believe that a person is in possession of proceed of corruption, he may take decision for provisional attachment of such property for maximum period of 90 days and ultimate decision is taken by special court constituted under the Act. ${ }^{30}$ Section 31 of Act 2013 empowers special court on prima facie satisfaction to pass order for confiscation of proceed of corruption subject to final disposal of case. Section 30 (4) of Act 2013 prescribes that when public servant is convicted on charges of corruption, the proceeds relatable to the offence under Prevention of Corruption is confiscated and vest in the Central Government.

Section 35 (1) Lokpal and Lokayuktas Act 2013provides that for trial of cases under Prevention of Corruption Act 1988 and Lokpal and Lokayuktas Act 2013 Central Government shall constitute such number of special courts as recommended by Lokpal. For effectively tackling corruption Section 35 (2) of Act 2013 prescribes one year duration to complete trial of case. Whenever trial is not completed in this stipulated time, then court has to give reason in writing and trial has to be completed in further three months. On conviction of public servant for commission of corruption, special court shall also calculate that how much loss is caused to public exchequer and it has to be recovered from the public servant. ${ }^{31}$ When more periods are needed, it may be extended for three months each time. Section 44 of Lokpal and Lokayuktas Act 2013 requires that every public servant shall declare his assets and liabilities and also assets and liabilities of his spouse and dependent children. Such declaration has to be given by public servant every year before $31^{\text {st }}$ July.

Public servants are crucial officer for governance of country; this Act which establishes important authority to deal with corruption may be misused by some vested interest that may be interested in pressurizing honest public servant or affect his reputation; in such situation there is need to take action against person who files false complaint under this Act. Therefore, Section 46 (1) of Lokpal and Lokayukta Act 2013 declares filing false and frivolous or vexatious complaint under this Act as an offence punishable with imprisonment for a term which may extend to one year and with fine which may extend to one lakh rupees. Section 57 of Act 2013 declares that the provisions of this Act are in addition to, and not in derogation of any other law for time being in force. Lokpal has supervision, guidance and control over investigation, inquiry and prosecution in corruption

\footnotetext{
${ }^{28}$ Proviso to Section 20 (5) Lokpal and Lokayuktas Act 2013.

${ }^{29}$ Section 25 Lokpal and Lokayuktas Act 2013.

${ }^{30}$ Section 29 Lokpal and Lokayuktas Act 2013.

${ }^{31}$ Section 39 Lokpal and Lokayuktas Act 2013.
} 
cases punishable under Prevention of Corruption Act 1988. Lokpal has recommendation power in reference to establishment courts for trial of corruption cases. Further, Lokpal has power to recommend to Central Government regarding actions against public servant involved in corruption. Corruption cases may be filed through Central Vigilance Commission, directly to Central Bureau of Investigation and other investigation agencies; Lokpal considers only those cases in which complaint is filed before it. Lokpal cannot take direct action except preliminary inquiry, direction to various investigation agencies, supervision over prosecution, provisional attachment of property alleged of proceeds of corruption and recommendation to Government for actions against public servant. Special Court has Jurisdiction of trial in corruption cases. Proper functioning of Lokpal may prove a great success for criminal justice system in tackling of corruption. Lokpal may supervise, guide and control the law enforcement agencies dealing with corruption and may fill long requisite need of criminal justice system.

\section{Concluding Remarks}

Corruption is not only dangerous problem in itself but it is mother of various other problems which cumulative impact is complete damaging of social value system and social developmental process. When any socially offensive act becomes socially accepted and part of cultural notion then it becomes difficult for criminal justice system to tackle effectively. For proper tackling it is necessary that society, members of society and also person indulged in the offensive act should consider that act concern is delinquent, offensive and undesired act. Further, corrupt person should consider that his corrupt activities have caused graver and serious harm to whole society and nation.

Corruption relating activities are committed during performance of official duty, thereby, it is always difficult to identify whether corruption was committed or it was performance of official duty. When gratification is obtained by misappropriation of public fund, no complaint is made by any person. Further, when gratification is given by any Person, he is benefitted by corruption, thereby, he does not lodge complaint. Complainant also fears for retaliatory action against him as alleged person has power, position and status. Generally, in corruption matters complaints are not filed by affected persons which affect registering and recording of criminal case. corruption is committed by public servants in course of performance of his professional duty in which they are expert, therefore, generally evidences are not available and even, if available those are not of traditional nature which creates problem in its collection, and further, during trial in evaluation and ultimately to decide corruption case and inflict punishment. Corruption is committed in organised manner. Investigation, prosecution and sentencing in corruption cases are serious challenges before criminal justice system. It is necessary to strengthen law enforcement agencies, procedure relating to investigation, prosecution, prescription of sufficient sentence, identification of illegal gratification and its confiscation. Recently enacted penal laws in India are enacted with due consideration of all the aforesaid requisites. Proper and effective 
enforcement of recently enacted penal laws may be efficiently tackle problem of corruption in India and pave the path of development of Indian society with proper pace and in appropriate direction.

\section{Cases}

Black Money (Undisclosed Foreign Income and Assets) and Imposition of tax Act, 2015 Criminal Procedure Code, 1973

Finance Act, 2019

Income Tax Act, 1961

Lokpal and Lokayuktas Act, 2013

Manu-smriti

Prevention of Corruption Act, 1988

Prevention of Corruption (Amendment) Act, 2018

Prevention of Money Laundering Act, 2002

Prohibition of Benami Property Transactions Act, 1988

Benami Transactions (Prohibition) Amendment Act, 2016

United Nations Convention against Corruption, 2003

United Nations Convention against Transnational Organised Crime, 2000 
